\title{
The Quality Of Life of Patients as a Criterion of Efficacy of Primary Open Angle Glaucoma Therapy
}

\author{
Kryvoviaz O.V. \\ Pharmacy department, Vinnytsia national Pyrohov memorial medical university, Ukraine
}

\begin{abstract}
QOL score in patients is one of the most important of therapy efficacy indicators for treatment of ophthalmic diseases, such as primary open angle glaucoma (POAG). The main goal of treatment of patients with POAG is to stabilize the ocular pressure and to stop progression of the disease. The purpose of the study was to identify changes in QOL of patients with POAG in the progress of treatment using different medicines of SOlE group - 'Antiglaucoma medicines and miotics' (AGM). Our study involved 247 patients with $P O A G$, whose average age was $70.27 \pm 8.97$ years. These patients were questioned using a standardized ophthalmic glaucoma-specific QOL questionnaire developed by us, aimed at the study of symptoms`severity, as well as their impact on various spheres of patients`activity. This method provided an opportunity not only to analyze the nature of impact of the disease on the patients performance, but also presented a criterion for evaluating the efficacy of mono- and combined therapies, as well as revealed the feasibility of administration of AGM. It was found, that the most effective monotherapy was Lanotan, while Azopt was the lowest one. Combinations of AGM presented intermediate efficacy indicators in studied patients.
\end{abstract}

Keywords: mono- and combined therapies, primary open angle glaucoma, quality of life, therapy efficacy.

\section{Introduction}

According to WHO, a category of social quality of life (QOL) consists of 12 parameters, with health ranking first among them. Health is also ranked first among eight groups of QOL social indicators according to the Economic Commission for Europe [2]. Therefore, the study of QOL allowed us to perform integral assessment of changes in physical, mental and social functioning of an individual, based on his/her subjective impression, being influenced by a disease and its treatment $[1,5,6]$.

A shift of QOL score in patients is one of the most important of therapy efficacy indicators for treatment of ophthalmic diseases, such as primary open angle glaucoma (POAG) [3, 4]. Eye diseases significantly affect the patients` QOL, leading to a reduction or total loss not only of working capacity, but also of the possibility to perform regular functions [7]. The main goal of treatment of patients with POAG is to stabilize the ocular pressure (OP) and to stop progression of the disease. Accordingly, a bundle of pharmacotherapy measures is aimed at the preservation of QOL score that is a demonstration of high efficacy of administered regimen $[3,5]$.

The purpose of the study was to identify changes in quality of life of patients with POAG in the progress of treatment using different medicines of S01E group - 'Antiglaucoma medicines and miotics'.

\section{Materials and Methods}

Our study involved 247 patients with eye pathology - POAG, whose average age was $70.27 \pm 8.97$ years. The total population, among others, included 68 patients with Grade I disease (67.88 \pm 10.13 years), and 61 patients with Grade III POAG (71.34 \pm 7.99 years). The most numerous was the group consisting of 83 patients aged $71.55 \pm 9.43$ years, diagnosed Grade II disease. The smallest number of patients -35 people aged average $69.97 \pm 6.49$ years - had Grade IV POAG.

The patients from the study population were questioned using a standardized ophthalmic glaucomaspecific quality of life questionnaire developed by us, aimed at the study of symptoms` severity, as well as their impact on various spheres of patients` activity (including physical and social ones). The questionnaire contains so-called 'passport' part with a diagnosis, patient's age and medications prescribed for POAG treatment. Five sections (39 questions) of the 'main' part characterize the overall physical health and vision status of patients, the assessment of social and routine activity, the severity of symptoms, as well as the assessment of compliance. This structure allowed us to estimate the impact of various therapy regimens on the quality of life of POAG patients, which was one of the most important indicators of therapy efficacy. The evaluation was conducted both in the whole study population, and in separate groups, depending on the disease severity. We analyzed the relationship between the quality of life and administered regimens, and their individual components.

The statistical data was processed using Statistika 10.0 software package and Microsoft Office Excel 2010. 


\section{Results of the Study}

The questioning using the above tool presented QOL score ranging from 60 to 172 points, averaged $111.91 \pm 17.46$. The patients evaluated general health condition $2-9$ points $(5.22 \pm 0.93$ in average $)$, social activity score within $6-30$ points $(19.93 \pm 3.94)$, routine activities -26 to 79 points $(49.37 \pm 8.96)$, and the severity of POAG symptoms - within $21-62$ points $(37.4 \pm 5.99$ in average). Evaluation of QOL of patients with different stages of POAG revealed the lowest score in Grade IV patients $(95.03 \pm 14.89)$, somewhat higher - in Grade III subjects - 106.85 \pm 16.99 , while the highest QOL score was observed in groups of patients with Grade I and II POAG (117.66 \pm 16.43 and $118.05 \pm 16.47$ points, respectively) (Table 1$)$.

Table 1 QOL in POAG patients

\begin{tabular}{|l|l|l|l|}
\hline \multirow{2}{*}{ POAG Grade } & \multicolumn{2}{|l|}{ QOL score } \\
\cline { 2 - 4 } & $\min$ & $\max$ & average \\
\hline I & 62 & 170 & $117.66 \pm 16.43$ \\
\hline II & 71 & 171 & $118.05 \pm 16.47$ \\
\hline III & 67 & 172 & $106.85 \pm 16.99$ \\
\hline IV & 60 & 152 & $95.03 \pm 14.89$ \\
\hline Regardless of the disease grade & 60 & 172 & $111.91 \pm 17.46$ \\
\hline
\end{tabular}

The questioned patients were administered different therapy regimens for treatment of POAG. In particular: Arutimol 0.5\%, Timolol 0,25\%, Azopt, Taflotan, and Lanotan monotherapy and Arutimol 0,5\% + Lanotan, Arutimol 0,5\% + Taflotan, Azopt + Taflotan combinations. Therefore, questionnaires were separated into 8 groups according to treatment regimens used by patients. Patients` QOL was evaluated within each group against general physical condition, social and routine activity indicators, followed by analysis of overall QOL score (Table 2).

Table 2 QOL score of POAG patients administered different therapy regimens

\begin{tabular}{|c|c|c|c|c|c|}
\hline \multirow[b]{2}{*}{ 亏్ } & \multirow{2}{*}{$\begin{array}{l}\text { Composition of POAG pharmacotherapy } \\
\text { regimen }\end{array}$} & \multicolumn{4}{|l|}{ QOL Score } \\
\hline & & $\begin{array}{l}\text { Physical } \\
\text { condition }\end{array}$ & Social activity & Routine activity & Total QOL Index \\
\hline 1 & Arutimol $0.5 \%$ & $5.28 \pm 0.81$ & $20.33 \pm 3.30$ & $48.38 \pm 7.27$ & $111.12 \pm 13.75$ \\
\hline 2 & Timolol $0.25 \%$ & $5.06 \pm 1.05$ & $20.73 \pm 3.72$ & $51.52 \pm 9.53$ & $117.94 \pm 19.87$ \\
\hline 3 & Azopt & $4.75 \pm 1.25$ & $19.00 \pm 4.00$ & $48.75 \pm 12.75$ & $103.75 \pm 22.75$ \\
\hline 4 & Taflotan & $5.17 \pm 0.83$ & $21.33 \pm 5.22$ & $52.67 \pm 11.33$ & $118.00 \pm 24.33$ \\
\hline 5 & Lanotan & $5.67 \pm 0.52$ & $23.56 \pm 5.28$ & $58.78 \pm 12.25$ & $132.33 \pm 27.26$ \\
\hline 6 & Arutimol $0.5 \%+$ Lanotan & $5.10 \pm 1.12$ & $18.30 \pm 5.18$ & $45.90 \pm 12.12$ & $102.80 \pm 21.44$ \\
\hline 7 & Arutimol $0.5 \%+$ Taflotan & $4.41 \pm 0.69$ & $16.86 \pm 3.76$ & $43.27 \pm 6.14$ & $99.77 \pm 12.67$ \\
\hline 8 & Azopt+Taflotan & $5.25 \pm 0.75$ & $17.50 \pm 4.50$ & $50.25 \pm 9.75$ & $107.25 \pm 22.65$ \\
\hline
\end{tabular}

Significant impact on quality of life indicator of patients had manifestation of POAG symptoms, therefore, we assessed the severity of symptoms in the above 8 groups of patients (Figure 1).

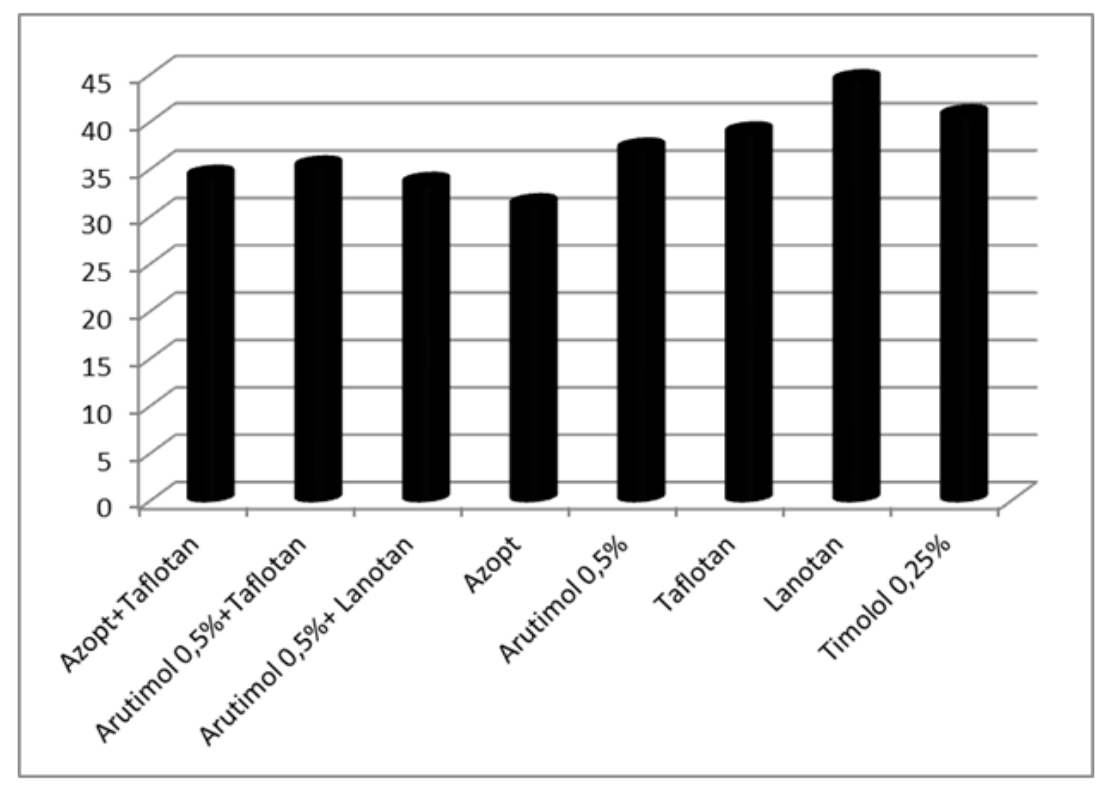

Figure 1- QOL Index by the severity of POAG symptoms. 
As seen from Table 2, the highest score of all quality of life indicators, including minimal level of symptoms`severity (Figure 1), presented patients administered Lanotan as an antiglaucoma pharmacotherapy. The lowest general health status, routine and social activity, and overall QOL score presented patients with POAG, administered Arutimol $0.5 \%$ in combination with Taflotan. The data shown in Figure 1 indicate that the greatest manifestation of POAG symptoms (lowest QOL score against this criterion) presented patients administered Azopt monotherapy.

For comprehensive evaluation of efficacy of treatment of POAG patients in terms of influence on patients`QOL, we conducted ranking of investigated antiglaucoma pharmacotherapy regimens in the context of overall QOL index of patients, the severity of POAG symptoms, and OP drop rate (Table. 3).

Table 3 Comprehensive evaluation of efficacy of different antiglaucoma regimens for POAG patients`QOL and OP drop rate

\begin{tabular}{|l|l|l|l|}
\hline $\begin{array}{l}\text { Composition of POAG pharmacotherapy } \\
\text { regimen }\end{array}$ & $\begin{array}{l}\text { A degree of IOP reduction } \\
\text { compared to baseline, } \%\end{array}$ & Total index of QL & $\begin{array}{l}\text { QOL by } \\
\text { symptoms }\end{array}$ \\
\hline Azopt+Taflotan & $40.04 \pm 7.59$ & $107.25 \pm 22.67$ & $34.25 \pm 6.88$ \\
\hline Arutimol 0.5\%+Taflotan & $39.09 \pm 7.73$ & $99.77 \pm 12.67$ & $35.23 \pm 4.41$ \\
\hline Arutimol 0.5\%+ Lanotan & $37.55 \pm 6.8$ & $102.80 \pm 21.44$ & $33.50 \pm 5.80$ \\
\hline Azopt & $35.5 \pm 5.6$ & $103.75 \pm 22.75$ & $31.25 \pm 4.75$ \\
\hline Arutimol 0.5\% & $34.75 \pm 8.86$ & $111.12 \pm 13.75$ & $37.12 \pm 4.86$ \\
\hline Taflotan & $22.82 \pm 5.6$ & $118.00 \pm 24.33$ & $38.83 \pm 9.56$ \\
\hline Lanotan & $21.03 \pm 7.18$ & $132.33 \pm 27.26$ & $44.33 \pm 9.70$ \\
\hline Timolol 0.25\% & $17.68 \pm 6.98$ & $117.94 \pm 19.87$ & $40.64 \pm 7.10$ \\
\hline
\end{tabular}

We compiled a sample of POAG therapy regimens by decreasing order of their performance while analyzing the data of Table 3 (Figure 2).

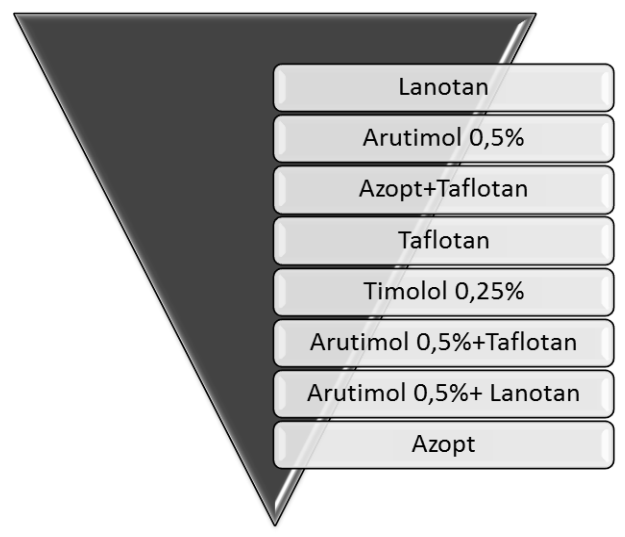

Figure 2-POAG therapy regimens`efficacy in decreasing order

\section{Conclusion}

The method for assessment of quality of life of patients with POAG used in our work provided an opportunity not only to analyze the nature of impact of the disease on the patients performance, but also presented a criterion for evaluating the efficacy of mono- and combined therapies, as well as revealed the feasibility of administration of antiglaucoma medicines. It was found, that the most effective monotherapy was Lanotan, while Azopt was the lowest one. Combinations of antiglaucoma medicines presented intermediate efficacy indicators in studied patients.

\section{References}

[1]. L.D. Fairclaugh, Design and Analysis of Quality of Life Studies in Clinical Trials (Charman \& Hall, CRC, 2002).

[2]. P. Kind, A. Williams, Measuring success in health care - the time has come to do it properly, Health Policy Matter, 9, $2004,1-8$.

[3]. O.Kryvoviaz, Antiglaucoma pharmacotherapy: analysis of treatment regimens and efficacy indicators, ScienceRise,. 3/4 (20), 2016, 46-50.

[4]. O.V. Makarenko, O.V. Kryvoviaz, Iu.O. Tomashevska, Vplyv dopomizhnykh rechovyn v protyhlaukomnykh ochnykh krapliakh na pokaznyk yakosti zhyttia za kryteriiem chastoty pobichnykh efektiv, Farmatsevtychnyi zhurnal, 3, 2015, 39-44.

[5]. O. V. Makarenko. E. V. Krivovyaz, Otsenka kachestva zhizni bolnykh pervichnoy otkrytougolnoy glaukomoy, Materialy nauchnoy konferentsii «Sovremennaya farmatsevtika: teoriya. praktika. eksperimenty», Moskow, RF, 2014, 48-53.

[6]. V.S. Luchkevich, Kachestvo zhizni kak obyekt sistemnogo issledovaniya $i$ integralnyy kriteriy otsenki zdorovia i effektivnosti mediko-profilakticheskikh i lechebno-reabilitatsionnykh program (SPbGMA im. I.I. Mechnikova, SPb, 2011).

[7]. N. V. Pasiechnikova, S. O. Rykov, O. P. Vitovska ta in., Sotsialni aspekty poperedzhennia slipoty, orhanizatsiia medychnoi dopomohy ta reabilitatsiia khvorykh na hlaukomu (TOV "Doktor-Media", Kyiv, 2009). 